This document was prepared in conjunction with work accomplished under Contract No. DE-AC09-96SR18500 with the U.S. Department of Energy.

This work was prepared under an agreement with and funded by the U.S. Government. Neither the U. S. Government or its employees, nor any of its contractors, subcontractors or their employees, makes any express or implied: 1 . warranty or assumes any legal liability for the accuracy, completeness, or for the use or results of such use of any information, product, or process disclosed; or 2 . representation that such use or results of such use would not infringe privately owned rights; or 3 . endorsement or recommendation of any specifically identified commercial product, process, or service. Any views and opinions of authors expressed in this work do not necessarily state or reflect those of the United States Government, or its contractors, or subcontractors. 


\title{
Investigation of the Thermodynamics Governing Metal Hydride Synthesis in the Molten State Process
}

Ashley C. Stowe, Polly A. Berseth, Thomas P. Farrell, Laura Laughlin, Donald Anton, Ragaiy Zidan*

Energy Security Directorate, Savannah River National Laboratory, Building 999-2W, Aiken, SC 29808

*Corresponding author: Tel: 18036468876

email: Ragaiy.Zidan@srnl.doe.gov (R. Zidan)

\begin{abstract}
Complex metal hydrides have been synthesized for hydrogen storage through a new synthetic technique utilizing high hydrogen overpressure at elevated temperatures (molten state processing). This synthesis technique holds the potential of fusing different complex hydrides at elevated temperatures and pressures to form new species with enhanced hydrogen storage properties. Formation of these compounds is driven by thermodynamic and kinetic considerations. We report on investigations of the thermodynamics. Novel synthetic complexes were formed, structurally characterized, and their hydrogen desorption properties investigated. The effectiveness of the molten state process is compared with mechanicosynthetic ball milling.
\end{abstract}

Keywords: A. metal hydrides A. hydrogen absorbing materials B. mechanicochemical processing $\mathbf{C}$. thermodynamic properties

\section{Introduction}

Efforts to develop an energy infrastructure based on consumption of hydrogen fuel have recently received renewed interest [1]. While the implementation of the Hydrogen Economy has many challenges, one of the greatest and most evident is storage of the fuel itself [2]. Hydrogen can be stored in a number of states, as a (i) compressed gas, (ii) 
cryogenic liquid, or (iii) component in a solid chemical media. The technical challenges faced include storage system, cost, safety, hydrogen densities (both gravimetric and volumetric), sustainability of the fuel component source, accessibility and efficiency of $\mathrm{H}_{2}$ "on demand", and purity of $\mathrm{H}_{2}$ stream [3]. Compressed gas allows for immediate hydrogen liberation at a low cost, but is volumetrically very inefficient. Liquid hydrogen is volumetrically very compact, but at a high cost of liquefaction. Solid state chemical storage of hydrogen can be compact and safe, but the added mass of the other chemical constituents must be minimized. Future hydrogen storage systems must have both high volumetric $\left(\geq 82 \mathrm{~g} \mathrm{H}_{2} \mathrm{~L}^{-1}\right)$ and gravimetric $\left(\geq 90 \mathrm{~g} \mathrm{H}_{2} \mathrm{~kg}^{-1}\right)$ densities of deliverable hydrogen to meet 2015 U.S. Department of Energy targets [4]. Further, these systems must release hydrogen at significant rates near $85-100{ }^{\circ} \mathrm{C}$, the temperature provided by the waste heat from a proton exchange membrane (PEM) fuel cell, to enhance efficiencies for use in transportation applications.

Numerous researchers have focused efforts on materials which store hydrogen in a solid form within a host lattice. This "host lattice" may either be a traditional interstitial intermetallic hydride such as $\mathrm{LaNi}_{5} \mathrm{H}_{6}$ in which hydrogen is incorporated into the interstitial sites of the $\mathrm{LaNi}_{5}$ lattice, or hydrogen may covalently bind with another element as is the case for alkali or alkaline earth metal hydrides such as $\mathrm{MgH}_{2}$ [5]. Another form of chemical bonding is physisorption of molecular $\mathrm{H}_{2}$ as has been observed in carbon structures [6-8] and metal organic framework compounds [9], although the observed hydrogen capacity in these materials has been limited to a few percent hydrogen by mass, under cryogenic conditions [6-9]. 
Chemical hydrides and complex metal hydrides have shown more promise as hydrogen storage materials due to their increased hydrogen densities. Ammonia borane $\left(\mathrm{NH}_{3} \mathrm{BH}_{3}\right)$, has been shown to release up to $13 \% \mathrm{H}_{2}$ by mass at a temperature less than $200^{\circ} \mathrm{C}[10]$. Further, it was found that when incorporated in mesoporous silica, the rates of hydrogen release increase by a factor of 1000 , and the dehydrogenation enthalpy was reduced to $-1 \mathrm{~kJ} / \mathrm{mol} \mathrm{H}_{2}$ (nearly thermoneutral) [11]. A major drawback of ammonia borane is that conditions for reversing hydrogenation have yet to be found.

Recent developments in complex metal hydride technology have created much excitement and stimulated many researchers to explore the potential of such materials as on-board hydrogen storage materials [12]. Bogdanovic and Schwickardi found that when a Ti-additive was introduced to $\mathrm{NaAlH}_{4}$, hydrogen desorption was catalyzed [13-15]. More importantly, the authors demonstrated that desorption of close to $5.5 \mathrm{wt} \% \mathrm{H}_{2}$ which could be desorbed at temperatures below $200{ }^{\circ} \mathrm{C}$, could be adsorbed back onto the spent material in a reversible fashion. While this breakthrough delivered a hydrogen storage material with far greater $\mathrm{H}_{2}$ capacity than traditional metal hydrides, organometallic synthesis methods were used to introduce the nano-particulate Ti-catalyst. Jensen, Zidan, and coworkers developed a method to disperse the Ti dopant throughout $\mathrm{NaAlH}_{4}$ using mechanical agitation thus simplifying sample preparation and enhancing kinetics [16]. Although Tidoped $\mathrm{NaAlH}_{4}$ has been shown to reversibly release hydrogen, absorption kinetics are currently slower than rates demanded for commercial applications.

Many other complex metal hydrides [17] and catalyst [18] materials have been investigated over the past decade; however, $\mathrm{NaAlH}_{4}$ remains the highest capacity material with good absorption kinetics under $200{ }^{\circ} \mathrm{C}$. Efforts to identify a novel hydrogen storage 
material with greater reversible capacity and good kinetic properties have followed a number of approaches including organometallic syntheses or mechanical-chemical agitation. $\mathrm{Ca}\left(\mathrm{AlH}_{4}\right)_{2}[19,20]$ and $\mathrm{Mg}\left(\mathrm{AlH}_{4}\right)_{2}[21,22]$ have recently been synthesized by organometallic synthetic techniques; however, it was found that once the alanate products form, they complex with the solvent to form very stable adducts. In many cases, the solvent adduct is more thermodynamically stable than the unsolvated alanate. This has been observed, for example, for aluminum hydride [23-25]. It should be noted that demonstration of reversible desorption from $\mathrm{Ca}\left(\mathrm{AlH}_{4}\right)_{2}, \mathrm{Mg}\left(\mathrm{AlH}_{4}\right)_{2}$, and $\mathrm{AlH}_{3}$ have not been successful. $\mathrm{CaAlH}_{5}$, the decomposition intermediate of $\mathrm{Ca}\left(\mathrm{AlH}_{4}\right)_{2}$, has thermodynamics suitable for rehydrogenation yielding a $3 \mathrm{wt} \% \mathrm{H}_{2}$ material [26]. Using a solid state metathesis reaction, $\mathrm{Ca}\left(\mathrm{AlH}_{4}\right)_{2}, \mathrm{Mg}\left(\mathrm{AlH}_{4}\right)_{2}$, and $\mathrm{AlH}_{3}$ have subsequently been synthesized by mechanical agitation, thereby circumventing the solvent complex. After milling, the desired metal hydride was separated from alkali halide byproducts with the use of solvents [27].

Reversibility of hydrogen in metal hydrides is an important aspect of the materials' properties. Although many such materials have sufficient capacities, the rehydriding conditions are too severe for on-board automotive applications. The van't Hoff plot (Figure 1) gives an indication of the thermodynamic stability of various metal hydrides. The inner box, containing just a few materials, represents the temperature $\left(60-160{ }^{\circ} \mathrm{C}\right)$ and pressure (1-100 bar) limits which are considered feasible for on-board hydrogen recharging of fuel materials of automotive applications and corresponds to desorption enthalpies of $\sim 20-40$ $\mathrm{kJ} / \mathrm{mol}$. Few known materials intersect this inner box and extensive efforts to synthesize new high capacity materials which do have appropriate properties is underway. 
Zidan and coworkers have demonstrated a newly developed technique which takes advantage of enhanced ionic diffusion resulting from elevated temperatures and pressures to synthesis novel metal hydride materials [28, 29]. This process, referred to as the Molten State Process (MSP), involves application of sufficient pressures to suppress dehydrogenation from metal hydride compounds while they are heated to temperatures near or beyond their melting point, such that the reactants form a semi-molten or molten mixture. The ions are thus allowed to diffuse with heightened mobility and activity, enhancing the probability for chemical reaction. Preparation of Ti-doped $\mathrm{NaAlH}_{4}$ under MSP conditions has been shown to enhance desorption kinetics beyond simply ball milling the catalyst and hydride. The fundamental physics which underlie the MSP process have yet to be investigated. This study was undertaken to investigate the thermodynamics and chemical kinetics of processing solid state hydrogen storage materials under combined high temperature and pressure conditions. This investigation will lead to a much better understanding of the utility of this new synthetic technique and the possibilities of synthesizing new compounds with higher hydrogen capacities than have been hither to uncovered.

\section{Experimental}

Reagent hydrides were purchased commercially and used as received. Due to the reactivity of these materials with moisture and air, all handling was conducted under an inert atmosphere within a dried and deoxygenated argon glove box. Appropriate molar quantities of the reagents (outlined in Table 1) were combined in a $65 \mathrm{~mL}$ Spex 8000 ball mill vial with four $6.35 \mathrm{~mm}$ and two $12.7 \mathrm{~mm}$ stainless steel balls at room temperature under a dry argon atmosphere. Once sealed, the reagents were milled for a total of 60 
minutes to homogenize the powder mixture. Milling typically resulted in a reduction of particle size without chemical reaction. However, due to mechanical energy transfer, heating during milling resulted in some reaction, as was the case for the $\mathrm{NaAlH}_{4}$ and $\mathrm{KH}$ (1:2 molar ratio) combination. A 4 mol $\% \mathrm{TiCl}_{3}$ addition was included in all reactions with $\mathrm{NaAlH}_{4}$ to catalyze rehydrogenation during MSP.

The milled reagents were placed in a high temperature/pressure reactor for synthesis by MSP [27]. A pressure of 272 bar (4000 psig), and a temperature of $200{ }^{\circ} \mathrm{C}$ were maintained for two hours. All reactions were preformed under these conditions except reactions involving $\mathrm{Mg}\left(\mathrm{AlH}_{4}\right)_{2}$ and $\mathrm{Ca}\left(\mathrm{AlH}_{4}\right)_{2}$ - either as a reagent or product. Reactions involving these materials were conducted at $80{ }^{\circ} \mathrm{C}$. X-Ray powder diffraction (XRD) was used to characterize the products, using $\mathrm{Cu} \mathrm{K}_{\alpha}$ radiation.

\section{Results and Discussion}

The reactions which have been investigated to probe the thermodynamics that dictate the synthesis in the molten state process are tabulated in Table 1. The effectiveness of the MSP conditions in the formation of $\mathrm{NaMgH}_{3}$ has previously been shown [29]. The introduction of high $\mathrm{H}_{2}$ pressure - at temperatures above the reagent hydride's melting point — increases diffusion and thereby enhances the probability of forming novel hybrid complex metal hydrides which can have high hydrogen capacity.

A reaction involving Ti-catalyzed $\mathrm{NaAlH}_{4}$ is ideal for current MSP conditions. The elevated $\mathrm{H}_{2}$ pressure prevents dehydriding such that $\mathrm{NaAlH}_{4}$ melts. The molten hydride will diffuse much more readily thereby enhancing the probability of complete chemical reactions. In the presence of equimolar quantities of $\mathrm{KH}$ (reaction 1),

$$
\mathrm{NaAlH}_{4}+\mathrm{KH} \rightarrow \mathrm{KAlH}_{4}+\mathrm{NaH}
$$


nearly complete ion exchange occurs to form the more thermodynamically stable $\mathrm{KAlH}_{4}$ as is shown in Figure 2. While the binary hydride free energies are similar $\left(\Delta \mathrm{G}_{\mathrm{f}}{ }^{\mathrm{o}}=\sim-30\right.$ $\mathrm{kJ} / \mathrm{mol}$ ), $\mathrm{KAlH}_{4}$ is nearly $50 \mathrm{~kJ} / \mathrm{mol}$ more thermodynamically stable than $\mathrm{NaAlH}_{4}$. This gives a free energy of reaction of $-50 \mathrm{~kJ} / \mathrm{mol}[30]$. Ball milling $\mathrm{NaAlH}_{4}$ and $\mathrm{KH}$ for 60 min results in only $\sim 10 \%$ ion exchange. The MSP synthetic conditions result in enhanced yields of $\mathrm{KAlH}_{4}$. A similar result was observed when sodium alanate was replaced with lithium alanate in reaction $1 . \mathrm{LiH}$ has a free energy some $30 \mathrm{~kJ} / \mathrm{mol}$ more stable than $\mathrm{NaH}$, therefore the exchange reaction should proceed more efficiently. During ball milling, this is in fact the case as approximately $70 \%$ ion exchange to form $\mathrm{KAlH}_{4}$ was observed. The reaction is complete under MSP conditions.

When the molar ratio of reagent hydrides is altered, novel complex metal hydride species were observed. In reaction 2 , more $\mathrm{KH}$ is added to reach a stoichiometric amount for formation of the mixed metal aluminum hexahydride $\mathrm{NaK}_{2} \mathrm{AlH}_{6}$.

$$
\mathrm{NaAlH}_{4}+2 \mathrm{KH} \rightarrow \mathrm{NaK}_{2} \mathrm{AlH}_{6}
$$

Alkali aluminum tetrahydrides have been previously shown to thermally decompose to the alkali aluminum hexahydride species with the deposition of $\mathrm{Al}$ and release of $\mathrm{H}_{2}$ [31]. $\mathrm{NaK}_{2} \mathrm{AlH}_{6}$ can be readily formed by ball milling alone [32] as well as by the molten state process as is shown in Figure 3. Sorby et al. [33] found that $\mathrm{NaK}_{2} \mathrm{AlH}_{6}$ is more thermodynamically stable than both $\mathrm{Na}_{3} \mathrm{AlH}_{6}$ and $\mathrm{K}_{3} \mathrm{AlH}_{6}$. When these two alkali aluminum hexahydrides were milled together, only the $\mathrm{NaK}_{2} \mathrm{AlH}_{6}$ resulted. It should be noted that no evidence of either $\mathrm{Na}_{3} \mathrm{AlH}_{6}$ or $\mathrm{K}_{3} \mathrm{AlH}_{6}$ were observed in the XRD pattern after MSP. Similar results were observed for the chemistry between $\mathrm{LiAlH}_{4}$ and $\mathrm{KH}$ in both equimolar and $\mathrm{KH}$ rich compositions (see Table 1). 
When potassium hydride is replaced with magnesium hydride in the compositions discussed above, ion exchange to form $\mathrm{Mg}\left(\mathrm{AlH}_{4}\right)_{2}$ does not occur. As shown in reaction 3,

$$
\mathrm{NaAlH}_{4}+\mathrm{MgH}_{2} \rightarrow \mathrm{NaMgH}_{3}+\mathrm{Al}+3 / 2 \mathrm{H}_{2}
$$

the reaction with $\mathrm{NaAlH}_{4}$ proceeds with formation of a stable ternary hydride with $6 \mathrm{wt} \%$ $\mathrm{H}_{2}$ [34-37]. During ball milling, only the reactant hydrides are observed; however, under the more energetic MSP conditions, $\mathrm{NaMgH}_{3}$ is observed in nearly complete yield (Figure 4). This material has been synthesized previously by ball milling [38] and recently, by molten state processing from the elements and binary hydrides [29]. There is a thermodynamic explanation for this difference; $\mathrm{Mg}\left(\mathrm{AlH}_{4}\right)_{2}$ is thermodynamically unstable with respect to the starting materials [38-40] while $\mathrm{NaMgH}_{3}$ has a formation enthalpy of $\Delta \mathrm{H}_{\mathrm{f}}=-231 \mathrm{~kJ} / \mathrm{mol}$ [41]. This formation enthalpy makes $\mathrm{NaMgH}_{3}$ more thermodynamically stable than $\mathrm{MgH}_{2}$ and $\mathrm{NaH}$ as well.

Interestingly, when $\mathrm{LiAlH}_{4}$ is used as the reactant alanate, no reaction is observed under milling or MSP conditions. $\mathrm{Mg}\left(\mathrm{AlH}_{4}\right)_{2}$ is again not expected; however, the formation enthalpy of $\mathrm{NaAlH}_{4}$ and $\mathrm{LiAlH}_{4}$ as essentially identical such that one might expect the analogous $\mathrm{LiMgH}_{3}$ material to be formed. $\mathrm{LiMgH}_{3}$ was first isolated via wet chemical organometallic synthesis by Ashby and Goel [42], but little is known of the ternary hydride $[43,44]$ in contrast with its sodium counterpart $[32,34-39,43] . \mathrm{LiMgH}_{3}$ is clearly less thermodynamically stable than $\mathrm{NaMgH}_{3}$ based on the present results. Ikeda et al. recently reported on the mechanicochemical synthesis of various perovskite-type ternary hydrides including $\mathrm{Li}_{0.5} \mathrm{Na}_{0.5} \mathrm{MgH}_{3}$ [38]. They observed no evidence of $\mathrm{LiMgH}_{3}$ formation and the authors suggest that this material will not form due to geometric restrictions of the lithium cation based on the Goldsmith tolerance factors under solid state conditions. 
To this point, the chemistry has been governed by the thermodynamic stability of the metal hydride product. If, however, the thermodynamic path to the desired metal hydride product requires formation of a less stable species (for example $\mathrm{Mg}\left(\mathrm{AlH}_{4}\right)_{2}$ or $\left.\mathrm{Ca}\left(\mathrm{AlH}_{4}\right)_{2}\right)$, one must provide an alternative thermodynamic route in order to drive the reaction toward the unstable thermodynamic complex metal hydride species. Introduction of a metal halide salt has been proven to result in synthesis of $\operatorname{Mg}\left(\mathrm{AlH}_{4}\right)_{2}[21,22]$ and $\mathrm{Ca}\left(\mathrm{AlH}_{4}\right)_{2}[19,20]$. The metathesis reaction is driven by formation of a very stable salt such as $\mathrm{LiCl}$ as shown in reactions 4 and 5 .

$$
\begin{aligned}
& \mathrm{MgCl}_{2}+2 \mathrm{LiAlH}_{4} \rightarrow \mathrm{Mg}\left(\mathrm{AlH}_{4}\right)_{2}+2 \mathrm{LiCl} \\
& \mathrm{CaCl}_{2}+2 \mathrm{LiAlH}_{4} \rightarrow \mathrm{Ca}\left(\mathrm{AlH}_{4}\right)_{2}+2 \mathrm{LiCl}
\end{aligned}
$$

Until very recently, all of the synthetic routes involved wet chemical methods which result in a solvent adduct [21-24]. The solvent adduct stabilizes the alanate structure and removal of the complexed solvent is very difficult.

Using the MSP technique, $\operatorname{Mg}\left(\mathrm{AlH}_{4}\right)_{2}$ has been synthesized by reaction 4 without solvent or ball milling (Figure 5). However, at molten state temperatures, the dehydrogenation products $\mathrm{MgH}_{2}, \mathrm{Al}$, and $\mathrm{H}_{2}$, as well as $\mathrm{LiCl}$ (from the initial metathesis reaction) are observed. At lower MSP temperatures, $\operatorname{Mg}\left(\mathrm{AlH}_{4}\right)_{2}$ is stabilized without decomposition. One should note that these temperatures do not achieve a truly "molten state"; however, the increased thermal energy maximizes diffusion without initiating dehydrogenation of $\operatorname{Mg}\left(\mathrm{AlH}_{4}\right)_{2}$, which occurs at approximately $150{ }^{\circ} \mathrm{C}$ [45]. The formation of $\mathrm{LiCl}$ thermodynamically drives the metathesis reaction toward formation of the unstable alanate. Further, if $\mathrm{NaAlH}_{4}$ is used such that $\mathrm{NaCl}$ is formed, the reaction is more 
spontaneous due the greater stability of $\mathrm{NaCl}$ with respect to $\mathrm{LiCl}$. A similar result is observed for reaction 5 resulting in the formation of $\mathrm{Ca}\left(\mathrm{AlH}_{4}\right)_{2}$.

\section{Conclusions}

The molten state process provides another synthetic methodology in the effort to develop new high capacity, reversible hydrogen storage materials. High hydrogen pressures prevent reactants from decomposing at molten temperatures. While diffusion is greatly enhanced due to the elevated temperature and pressure conditions, diffusion alone does not dictate the resultant chemistry. It is clear that thermodynamics are a key factor in successful synthesis of targeted materials during processing with the MSP technique. The reaction of $\mathrm{NaAlH}_{4}$ with $\mathrm{MgH}_{2}$ resulted in the formation of a more thermodynamically stable product $\mathrm{NaMgH}_{3}$. A similar result has been observed when $\mathrm{MgH}_{2}$ is replaced by $\mathrm{Mg}_{2} \mathrm{NiH}_{4}$ in MSP [46]. $\mathrm{Mg}\left(\mathrm{AlH}_{4}\right)_{2}$ is not observed to form in this reaction unlike the reaction involving $\mathrm{NaAlH}_{4}$ and $\mathrm{KH}$. $\mathrm{KAlH}_{4}$ and $\mathrm{NaH}$ result from the latter reaction due to the greater thermodynamic stability of $\mathrm{KAlH}_{4}$ with respect to $\mathrm{NaAlH}_{4}$. Further, by controlling the stoichiometry of reactants, the ultimate reaction products can be altered within thermodynamic constraints. Changing the molar ratio of $\mathrm{NaAlH}_{4}$ to $\mathrm{KH}$ results in formation of $\mathrm{NaK}_{2} \mathrm{AlH}_{6}$ rather than $\mathrm{KAlH}_{4}$. When the desired product is not thermodynamically stable with respect to the starting materials, a thermodynamic "sink"such as alkali halide salts — can be used to favor the desired product. A metathesis reaction between $\mathrm{MgCl}_{2}$ and $\mathrm{LiAlH}_{4}$ will result in the formation of $\mathrm{Mg}\left(\mathrm{AlH}_{4}\right)_{2}$ and $\mathrm{LiCl}$.

$\mathrm{Mg}\left(\mathrm{AlH}_{4}\right)_{2}$ is thermodynamically unstable; however, the formation of $\mathrm{LiCl}$ as a co-product in the reaction causes the overall reaction to proceed. It should also be noted that reaching a true molten state-i.e. temperatures sufficient to melt reactants—is not strictly required. 
In the case of $\mathrm{Mg}\left(\mathrm{AlH}_{4}\right)_{2}$, thermal energy below the melting point of $\mathrm{NaAlH}_{4}$ resulted in formation of the kinetically stabilized complex metal hydride.

It should be emphasized that kinetic factors must have their role in formation and stabilization of products. $\mathrm{AlH}_{3}$, for example, is thermodynamically unstable and should decompose to $\mathrm{Al}$ metal and hydrogen under ambient conditions. It is believed that due to formation of a surface oxide layer, the material has been shown to have less than $1 \%$ decomposition after nearly $30 \mathrm{yrs}$ [47]. The role of kinetics in the synthesis and stabilization of complex hydride materials by MSP will be investigated in future studies.

Many complex metal hydride materials have equilibrium pressures far greater than the highest employed MSP pressures $\left(\sim 4500 \mathrm{psi}_{2}\right)$; therefore the concept of creating a molten state while preventing dehydrogenation requires higher pressures than used in this study. These materials can begin decomposing during (if not before) they become molten thereby reducing the reaction yield. Further, if the MSP conditions do lead to a novel material with less stability, the lack of sufficient $\mathrm{H}_{2}$ pressure will prevent isolation of such a material. The molten state process could be improved as a synthetic tool if higher pressures could be applied.

\section{Acknowledgements}

The authors would like to thank Dr. Arthur Jurgensen, Jennifer Pittman, and Martin Scott for their contributions to this work. This work was funded through a grant from the US Department of Energy Office of Basic Energy Science. 


\section{References}

1. U.S. Department of Energy, Office of Basic Energy Sciences, Basic Research Needs for the Hydrogen Economy, U.S. DOE, Washington, DC (2004).

2. Recent information can be found at: http://www.eere.energy.gov/hydrogenandfuelcells.

3. S. Satyapal, J. Petrovic, C. Read, G. Thomas, G. Ordaz. Catalysis Today 120 (2007) 246.

4. http://www.eere.energy.gov/vehiclesandfuels/about/partnerships/freedomcar.

5. A. Zaluska, L. Zaluski, J.O. Ström-Olsen. Appl. Phys. A 72 (2001) 157.

6. F.L. Darkrim, P. Malbrunot, G.P. Tartaglia. Int. J. Hydrogen Energy 27 (2002) 193.

7. M. Hirscher, M. Becher, M. Haluska, F. Zeppelin, X. Chen, U. Dettlaff-Weglikowska. J. Alloys Compd. 356-357 (2003) 433.

8. M. Hirscher, M. Becher. J. Nanosci. Nanotech. 3 (2003) 3.

9. N.L. Rosi, J. Eckert, M. Eddaoudi, D.T. Vodak, J. Kim, M. O'Keefe, O.M. Yaghi, Science 300 (2003) 1127.

10. G. Wolf, J. Baumann, F. Baitalow, F.P. Hoffmann, Thermochimica Acta 343 (2000) 19.

11. A. Gutowska, L. Li, Y. Shin, C.M. Wang, X.S. Li, J.C. Linehan, R.S. Smith, B.D. Kay, B. Schmid, W. Shaw, M. Gutowski, T. Autrey. Angew. Chem. Int. Ed. 44 (2005) 3578.

12. A. Zuttel Mater Today (2003) 24.

13. B. Bogdanovic, M. Schwickardi Appl. Phys. A 72 (2001) 221.

14. B. Bogdanovic, M. Scwickardi. J. Alloys Compd. 253-254 (1997) 1.

15. B. Bogdanovic, R.A. Brand, A. Marjanovic, M. Schwickardi, J. Tölle. J. Alloys Compd. 302 (2000) 36.

16. C.M. Jensen, R. Zidan, N. Mariels, A. Hee, C. Hagena. Int. J. Hydrogen Energy 24 (1999) 461.

17. B. Sakintuna, F. Lamari-Darkrim, M. Hirscher, Int. J. Hydrogen Energy 32 (2006) 1121.

18. D. L. Anton, J. Alloys Compd. 356-357 (2003) 400.

19. M. Fichtner, C. Frommen, O. Fuhr. Inorg. Chem. 44 (2005) 3479.

20. M. Schwarz, A. Haiduc, H. Stil, P. Paulus, H. Geerlings. J. Alloys Compd. 404-406 (2005) 762.

21. E.C. Ashby, R.D. Schwartz, B.D. James. Inorg. Chem. 9 (1970) 325.

22. M. Fichtner, O. Fuhr. J. Alloys Compd. 345 (2002) 286.

23. A.E. Finholt, A.C. Bond, Jr., H.I. Schlesinger. J. Am. Chem. Soc. 69 (1947) 1199.

24. G. Chizinsky,G.G. Evans, T.R.P. Gibb, Jr., M.J. Rice, Jr. J. Am. Chem. Soc. 77 (1955) 3164.

25. F.M. Brower, N.E. Matzek, P.F. Reigler, H. Rinn, C.B. Roberts, D.L. Schmidt, J.A. Snover, K. Terada. J. Am. Chem. Soc. 98 (1976) 2450.

26. C. Wolverton, V. Ozolins. Phys. Rev. B 75 (2007) 064101.

27. M. Mamantha, B. Bogdanovic, M. Felderhoff, A. Pommerin, W. Schmidt, F. Schuth, C. Weidenthaler. J. Alloys Compd. 407 (2006) 78.

28. R. Zidan. US Patent No. 7094387 B2 (2006).

29. R. Zidan, K. Shanahan, D. Anton, A. Jurgensen, J. Pittman. Mater. Res. Soc. Symp. Proc. 885E (2006) 0885-A07-02.1-02.7.

30. The free energy of reaction was calculated from values in the JANAF thermodynamic database using the HSC thermodynamic package.

31. T.N. Dymova, Y.M. Dergachev, VA Sokolov, N.A. Grechanaya. Dokl Akad Nauk USSR 224 (1975) 591.

32. J. Greatz, Y. Lee, J.J. Reilly, S. Park, T. Vogt. Phys. Rev. B. 71 (2005) 184115.

33. M. Sorby, H. Brinks, A. Fossdal, K. Thorshaug, B. Hauback. J. Alloys Compd. 415 (2006) 284.

34. A. Bouamrane, J.P. Laval, J.-P. Soulie, J.P. Bastide. Mater. Res. Bull. 35 (2000) 545.

35. K. Ikeda, Y. Kogure, Y. Nakamori, S. Orimo. Scripta Materialia 53 (2005) 319.

36. E. Ronnebro, D. Noreus, K. Kadir, A. Reiser, B. Bogdanovic. J. Alloys and Compounds 299 (2000) 101.

37. K. Ikeda, Y. Kogure, Y. Nakamori, S. Orimo. Scripta Materialia 53 (2005) 319.

38. K. Ikeda, Y. Nakamori, S. Orimo. Acta Materialia, 53 (2005) 3453.

39. Y. Kim, E.-K. Lee, J.-H. Shim, Y. Cho, K. Yoon. J. Alloys Compd. 422 (2006) 283.

40. M. van Setten, G. Wijs, V. Popa, G. Brocks. Phys. Rev. B 72 (2005) 073107.

41. A. Bouamrane, C. de Brauer, J.-P. Soulie, J. Letoffe, J. Bastide. Thermochemica Acta 326 (1999) 37.

42. E. Ashby, A. Goel. Inorg. Chem. 17 (1978) 322.

43. Y. Li, B. Rao, T. McMullen, P. Jena, P. Khowash. Phys. Rev. B 44 (1991) 6030.

44. P. Khowash, B. Rao, T. McMullen, P. Jena. Phys. Rev. B 55 (1997) 1454.

45. A. Fossdal, H. Brinks, M. Fitchner, B. Hauback. J. Alloys Compd. 404-406 (2005) 752.

46. P.A. Berseth, J. Pittman, K. Shanahan, A.C. Stowe, D. Anton, R. Zidan. communicated (2007). 
47. G. Sandrock, J.J. Reilly, J. Graetz, W.-M. Zhou, J. Johnson, J. Wegrzyn. J. Alloys Compd. 421 (2006) 185. 


\section{Figure captions}

Figure 1. van't Hoff plot of various metal hydride hydrogen storage materials. The slope of each line represents the hydriding enthalpy.

Figure 2. The XRD pattern of $\mathrm{KAlH}_{4}$ and $\mathrm{NaH}$ which resulted from ion exchange in the MSP reaction of Ti-doped $\mathrm{NaAlH}_{4}$ and $\mathrm{KH}$. All reflections are representative of $\mathrm{KAlH}_{4}$ unless marked otherwise.

Figure 3. The XRD pattern $\mathrm{NaK}_{2} \mathrm{AlH}_{6}$ after milling Ti-doped $\mathrm{NaAlH}_{4}$ with $\mathrm{KH}$ for 60 minutes.

Figure 4. XRD pattern of $\mathrm{NaMgH}_{3}$ ( $\star$ ). MSP of Ti-doped $\mathrm{NaAlH}_{4}$ and $\mathrm{MgH}_{2}$ results in formation of the stable ternary hydride.

Figure 5. The XRD pattern is shown for the MSP synthesis of $\mathrm{Mg}\left(\mathrm{AlH}_{4}\right)_{2}(\star)$ at $80{ }^{\circ} \mathrm{C}$ and $4000 \mathrm{psi} \mathrm{H}_{2}$. The reaction is driven by formation of $\mathrm{LiCl}(\mathbf{O})$, resulting in formation of an unstable complex metal hydride. Some residual $\mathrm{Li}_{2} \mathrm{MgCl}_{4}$ may also be present. 


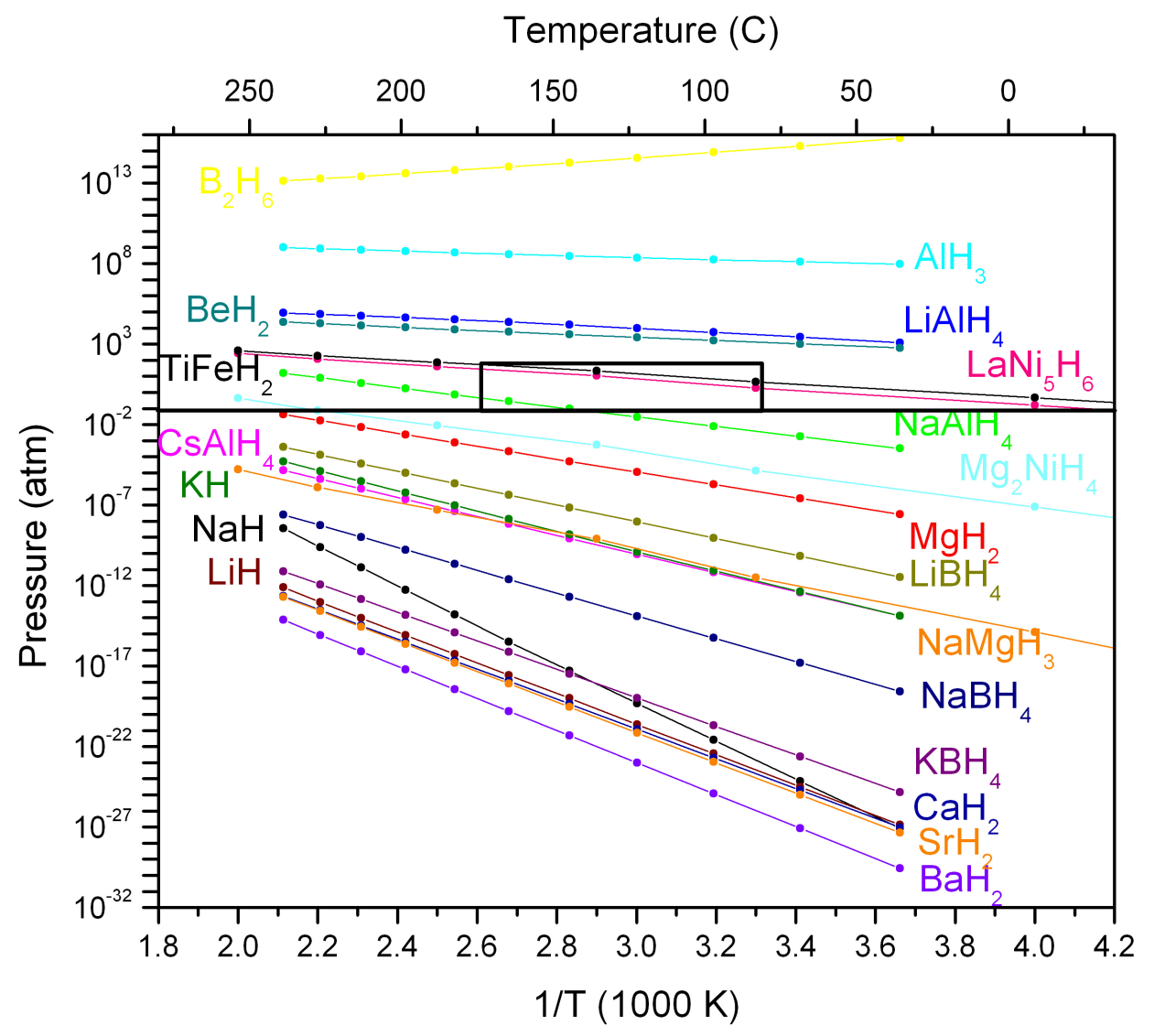

Figure 1 


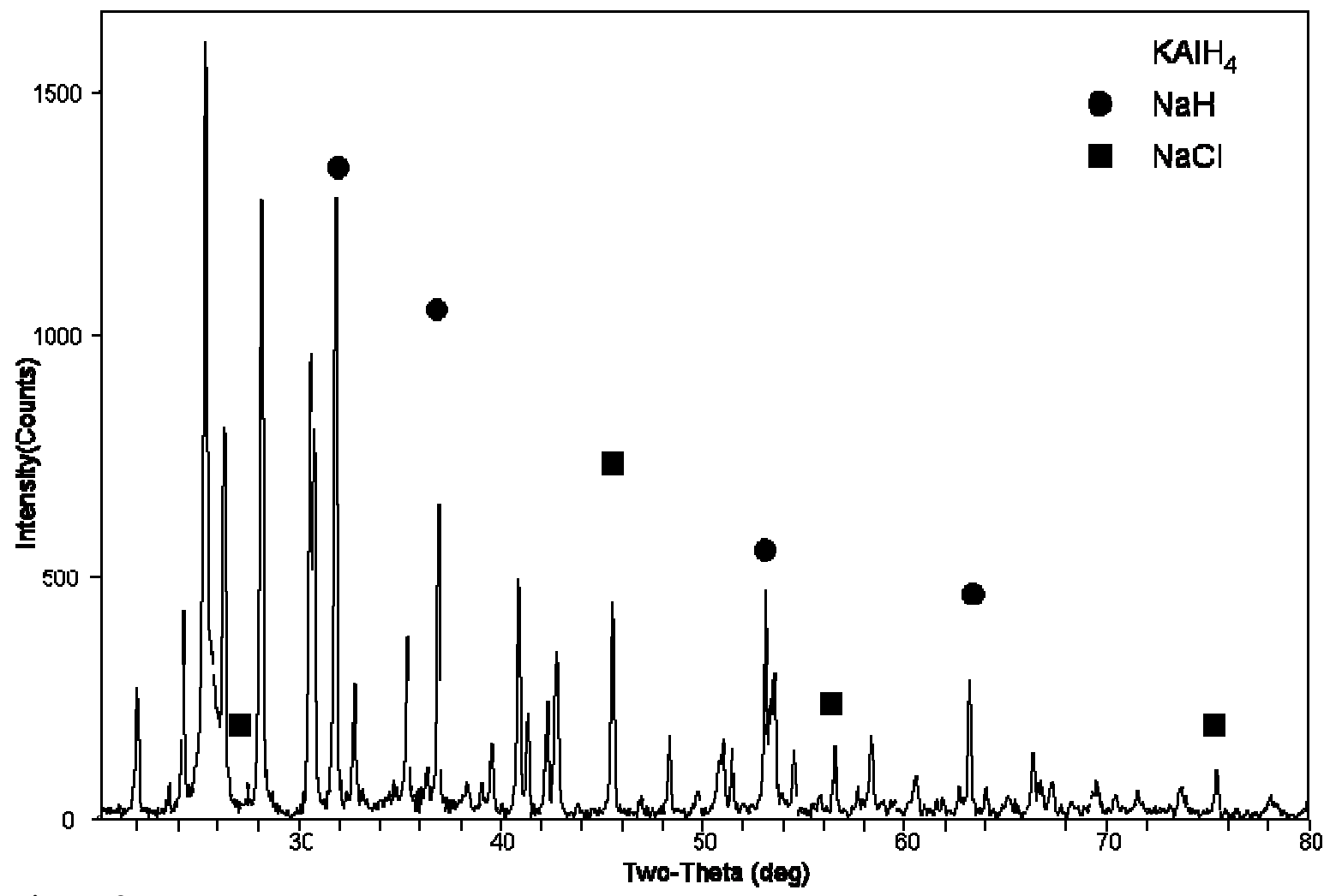

Figure 2. 


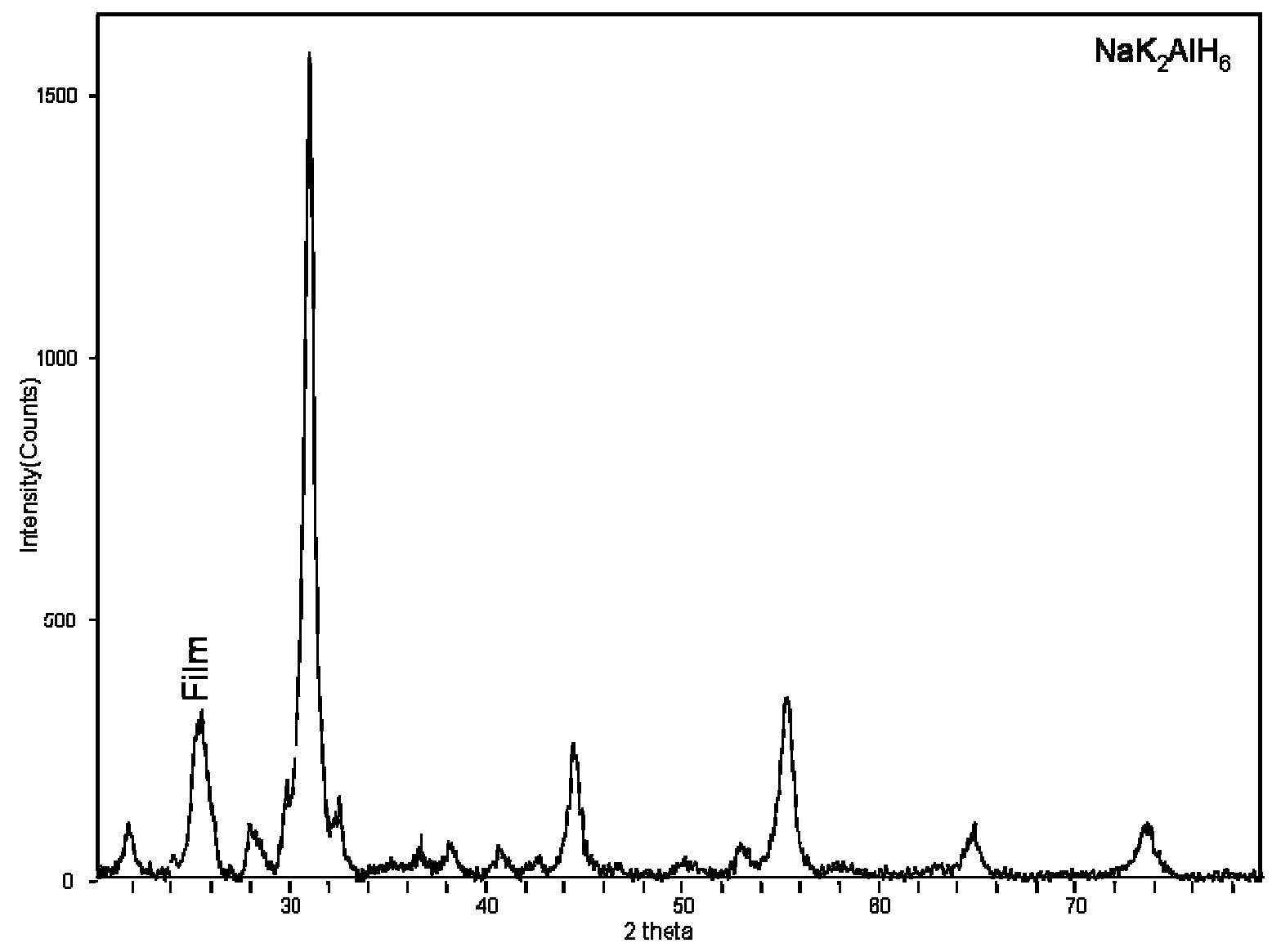

Figure 3. 


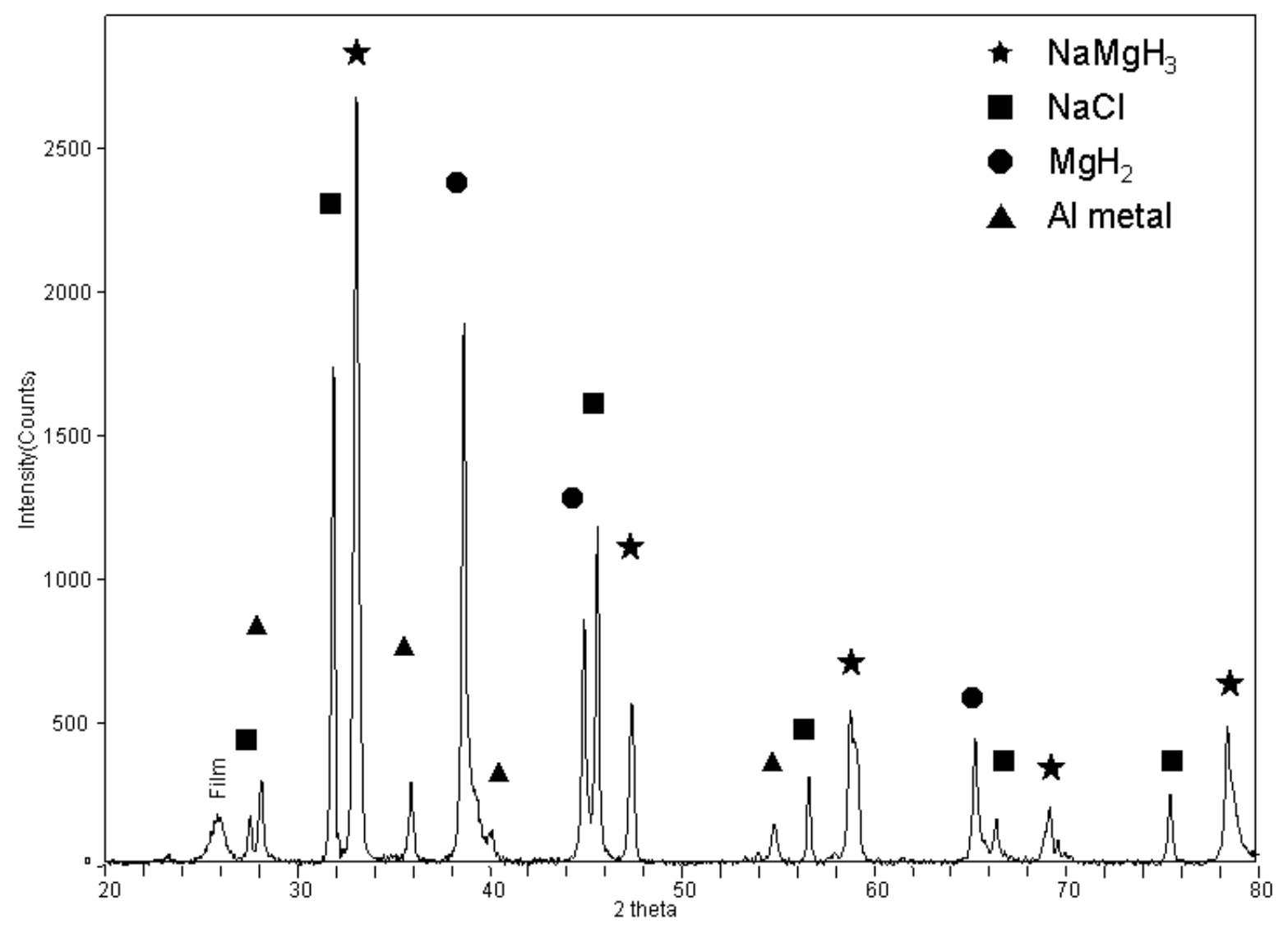

Figure 4. 


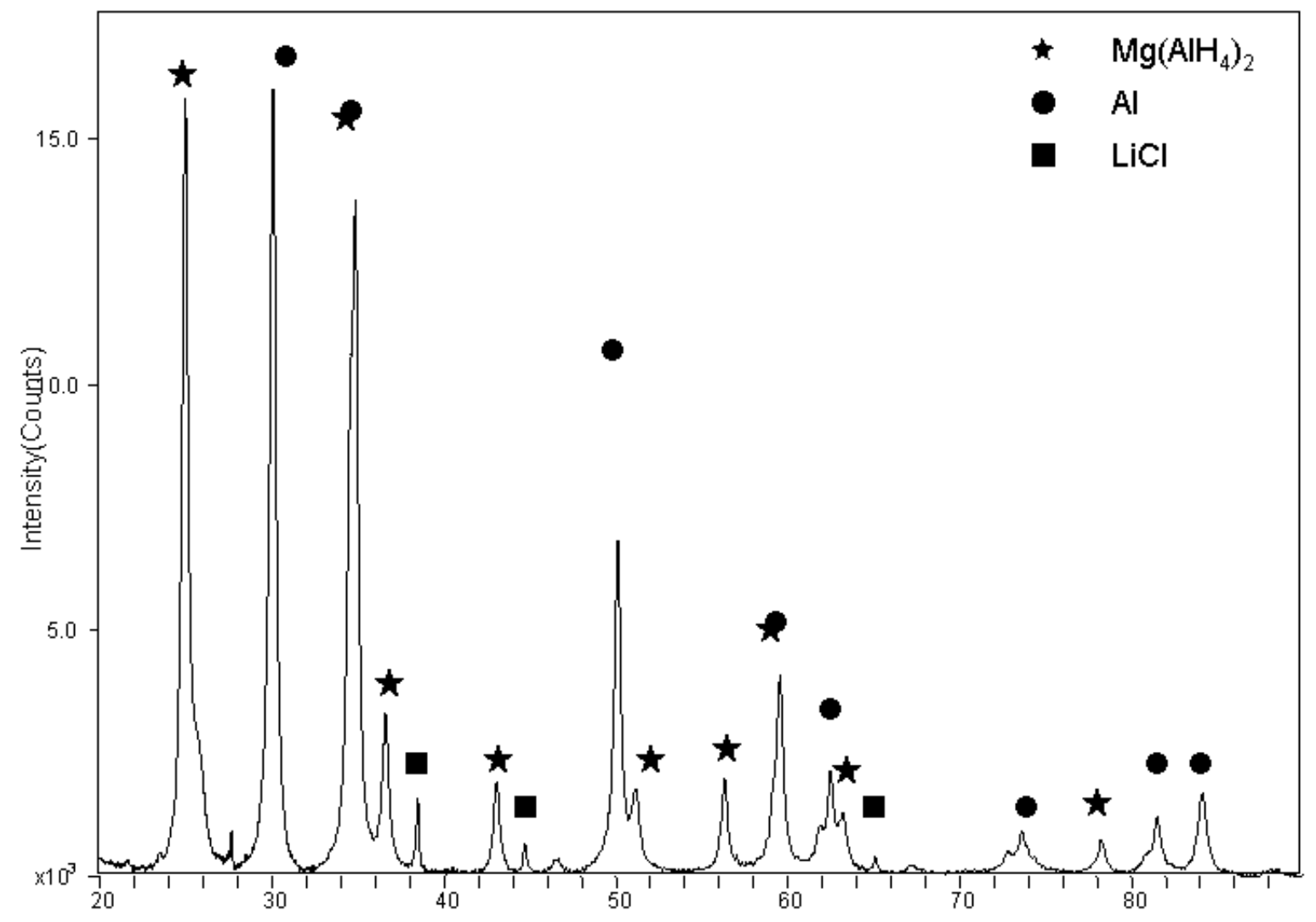

Figure 5. 
Table 1. Reaction matrix for the study of complex metal hydride synthesis thermodynamics by the Molten State Process (MSP).

\begin{tabular}{|c|c|c|c|}
\hline Reactants (mole ratio) & Cat. $^{a}$ & Milling products ${ }^{b}$ & MSP products ${ }^{c}$ \\
\hline $\mathrm{NaAlH}_{4} / \mathrm{KH}(1: 1)$ & $\mathrm{x}$ & $10 \%$ ion exchange & $\mathrm{KAlH}_{4} / \mathrm{NaH}$ \\
\hline $\mathrm{NaAlH}_{4} / \mathrm{KH}(1: 2)$ & $\mathrm{x}$ & $\mathrm{NaK}_{2} \mathrm{AlH}_{6}$ & $\mathrm{NaK}_{2} \mathrm{AlH}_{6}$ \\
\hline $\mathrm{LiAlH}_{4} / \mathrm{KH}(1: 1)$ & & $70 \%$ ion exchange & $\mathrm{KAlH}_{4} / \mathrm{LiH}$ \\
\hline $\mathrm{LiAlH}_{4} / \mathrm{KH}(1: 2)$ & & $\mathrm{LiK}_{2} \mathrm{AlH}_{6}$ & $\mathrm{LiK}_{2} \mathrm{AlH}_{6}$ \\
\hline $\mathrm{LiAlH}_{4} / \mathrm{MgH}_{2}(1: 1)$ & & no net reaction & no net reaction \\
\hline $\mathrm{NaAlH}_{4} / \mathrm{MgH}_{2}(1: 1)$ & $\mathrm{x}$ & no net reaction & $\mathrm{NaMgH}_{3} / \mathrm{Al}$ \\
\hline $\mathrm{CaCl}_{2} / \mathrm{LiAlH}_{4}(1: 2)$ & & $\mathrm{Ca}\left(\mathrm{AlH}_{4}\right)_{2} / \mathrm{LiCl}$ & $\mathrm{Ca}\left(\mathrm{AlH}_{4}\right)_{2} / \mathrm{LiCl}^{\mathrm{d}}$ \\
\hline $\mathrm{MgCl}_{2} / \mathrm{LiAlH}_{4}(1: 2)$ & & $\mathrm{Mg}\left(\mathrm{AlH}_{4}\right)_{2} / \mathrm{LiCl}$ & $\operatorname{Mg}\left(\mathrm{AlH}_{4}\right)_{2} / \mathrm{LiCl}^{\mathrm{d}}$ \\
\hline
\end{tabular}

